\title{
Excavation in a Historic Cemetery Milam Park Renovation Phase II
}

Cynthia L. Tennis

Center for Archaeological Research

Follow this and additional works at: https://scholarworks.sfasu.edu/ita

Part of the American Material Culture Commons, Archaeological Anthropology Commons, Environmental Studies Commons, Other American Studies Commons, Other Arts and Humanities Commons, Other History of Art, Architecture, and Archaeology Commons, and the United States History Commons

Tell us how this article helped you.

This Article is brought to you for free and open access by the Center for Regional Heritage Research at SFA ScholarWorks. It has been accepted for inclusion in Index of Texas Archaeology: Open Access Gray Literature from the Lone Star State by an authorized editor of SFA ScholarWorks. For more information, please contact cdsscholarworks@sfasu.edu. 


\section{Excavation in a Historic Cemetery Milam Park Renovation Phase II \\ Creative Commons License \\ (c) (1) \& 8}

This work is licensed under a Creative Commons Attribution-NonCommercial 4.0 International License 


\title{
EXCAVATION IN A HISTORIC CEMETERY
}

\section{MILAM PARK RENOVATION PHASE II}

\author{
Cynthia L. Tennis
}

with a contribution by

Douglas W. Owsley

Robert J. Hard, Principal Investigator

Texas Antiquities Permit No. 1338

Ocopyright

Center for Archaeological Research

The University of Texas at San Antonio

Archaeological Survey Report, No. 227 
The following information is provided in accordance with the General Rules of Practice and Procedure, Chapter 41.11 (Investigative Reports), Texas Antiquities Committee:

1. Type of investigation: monitoring and excavation

2. Project name: Milam Park, Phase II

3. County: Bexar

4. Principal investigators: Robert J. Hard

5. Name and location of sponsoring agency: San Antonio Department of Parks and Recreation, San Antonio, Texas

6. Texas Antiquities Committee Permit No.: 1338

7. Published by the Center for Archaeological Research, The University of Texas at San Antonio, San Antonio, Texas 78249-0658, 1995.

A list of publications offered by the Center for Archaeological Research is available. Call (210) $691-4378$ or write to the Center for Archaeological Research, The University of Texas at San Antonio, 6900 N. Loop 1604 West, San Antonio, Texas 78249-0658. 


\section{CONTENTS}

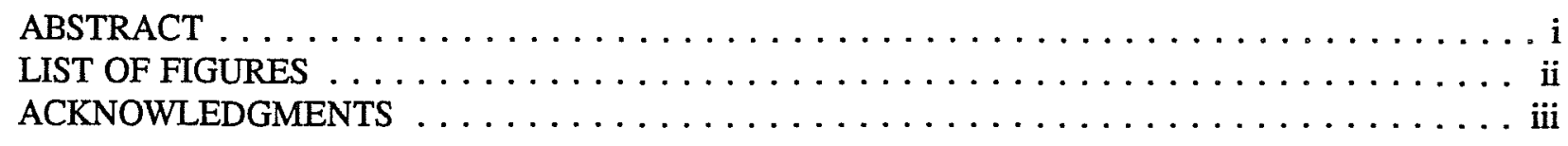

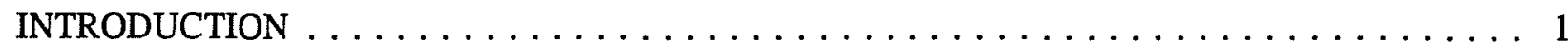

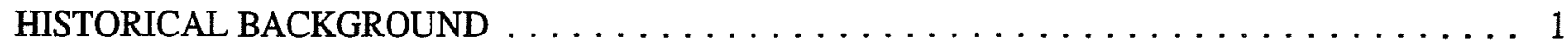

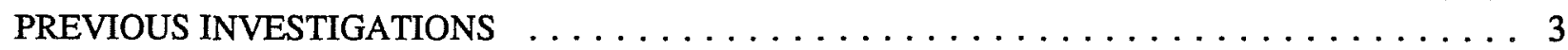

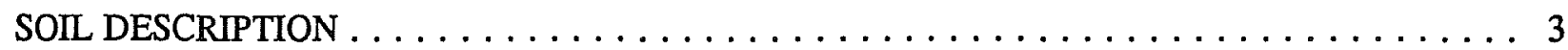

SHOVEL TESTS AND MONITORING $\ldots \ldots \ldots \ldots \ldots \ldots \ldots \ldots \ldots \ldots$

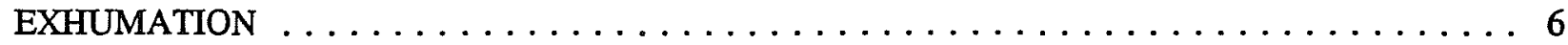

OSTEOLOGICAL ANALYSIS

Douglas W. Owsley and Cynthia L. Tennis $\ldots \ldots \ldots \ldots \ldots \ldots \ldots \ldots$

CONCLUSIONS AND RECOMMENDATIONS $\ldots \ldots \ldots \ldots \ldots \ldots \ldots \ldots \ldots \ldots \ldots$

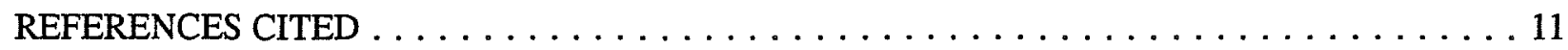

\section{FIGURES}

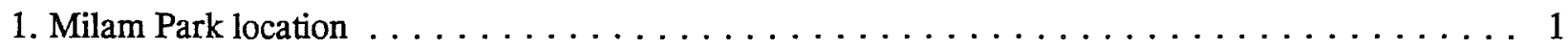

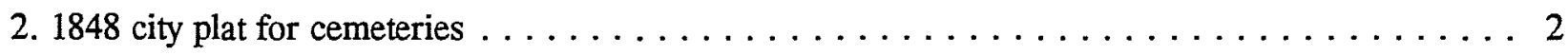

3. Site map showing monitored excavations and burial location $\ldots \ldots \ldots \ldots \ldots \ldots \ldots \ldots \ldots \ldots \ldots \ldots$

4. Plan view of burial $\ldots \ldots \ldots \ldots \ldots \ldots \ldots \ldots \ldots \ldots \ldots \ldots \ldots$

5.1847 Mexican 8 reales . . . . . . . . . . . . . . . . . . . . . 10 


\begin{abstract}
Phase II of archaeological investigations at Milam Park in downtown San Antonio, Texas, were conducted by staff members from the Center for Archaeological Research (CAR) of The University of Texas at San Antonio. This project consisted of shovel tests and monitoring of all excavations connected with construction and renovation activities at the park. Shovel tests were dug prior to ground alterations to assess the amount of recent fill dirt covering the historic surface of the park.

The assessment allowed identification of areas of the park that might be sensitive to construction impact. This information was used by the San Antonio Department of Parks and Recreation in planning new landscape features. Additionally, because Milam Park had once been a city cemetery, all ground leveling and grading operations, all new sewer and electric line trenching activities, and all light standard and tree planting excavations were monitored by CAR staff. One historic burial was encountered, exhumed, and analyzed.
\end{abstract}




\section{ACKNOWLEDGMENTS}

This report represents the culmination of more than a year of archaeological monitoring during the renovation of Milam Park in downtown San Antonio. During this period I had the opportunity to work with many local companies who volunteered their time and expertise to this project. I'd like to thank the project architect Jose Jimenez and the crews from Valero Energy Corporation, Van Delden Company, H. B. Zachry Company, Mission Plumbing, and Paul's Green Thumb Landscaping for their cooperation and their interest in the archaeology at the park. The Friends of Milam Park were instrumental in supporting the renovations and the archaeological work in the park. I greatly appreciated the continual support and professionalism of Dale Bransford, Julie Lipton, and the rest of the San Antonio Department of Parks and Recreation staff.
I would also like to acknowledge the many members of the CAR staff who participated in the project: Dr. Robert Hard, principal investigator, Waynne Cox, Kevin Gross, Dave Nickels, and Barbara Meissner, and our technical editor Marcie Renner. Kaylee Stallings drew the coin.

Finally, special thanks go to Dr. Douglas Owsley of the Department of Anthropology, National Museum of Natural History, Smithsonian Institution. His assistance and supervision of the skeletal analysis were a tremendous help to me and a significant addition to this report. 



\section{INTRODUCTION}

In October 1993, the Center for Archaeological Research (CAR) of The University of Texas at San Antonio (UTSA) was contracted by the San Antonio Department of Parks and Recreation to perform archaeological testing and monitoring connected with Phase II of the renovation of Milam Park (41BX922). Milam Park, located in downtown San Antonio, is bordered by Houston Street to the north, Commerce Street to the south, North San Saba Street to the west, and Santa Rosa Street on the east (Figure 1).

Phase II fieldwork, conducted under Texas Antiquities Committee Permit Number 1338, began November 1, 1993, and continued periodically until January 9,1995 , when the last tree was planted. This phase of work included a series of 15 shovel tests to assess the amount of recent fill dirt covering the historic surface of the park, thereby identifying areas of the park that might be sensitive to construction impact. Additionally, grading for access ramps and sidewalks; trenching for water, sewer, and electric lines; and excavating for tree planting and lamp

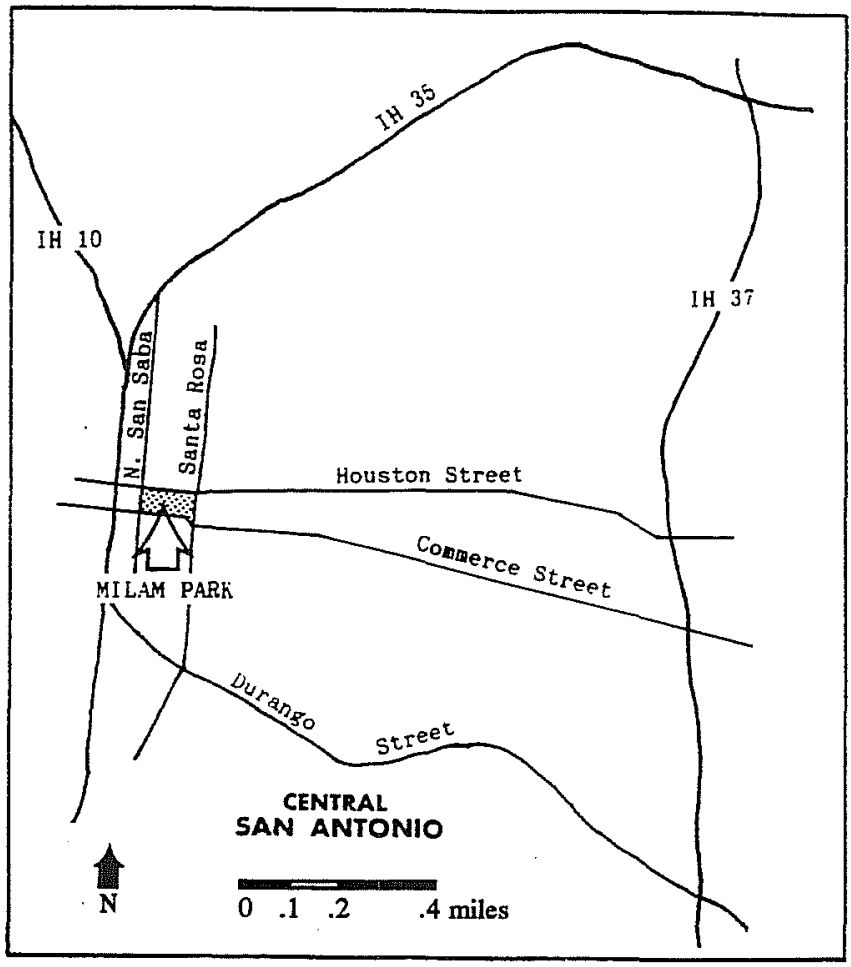

Figure 1. Milam Park location. pole installation were monitored. This level of work was required as the park had served as a city cemetery during the mid-1800s.

One Historic-period burial was encountered and exhumed by CAR staff. Analysis of these remains was conducted with the physical anthropological staff at the Smithsonian Institution. The remains are currently curated at the CAR laboratory facility. No other cultural resources were impacted.

\section{HISTORICAL BACKGROUND}

The official history of the block of land now known as Milam Park began April 3, 1848. On this date the city council, acting on a petition from the Catholic parish priest, adopted a resolution setting aside an eight-acre area adjoining and including the "old Campo Santo" for cemetery use (City Council Minutes [CCM], San Antonio City Hall, San Antonio, Texas, 1848, Volume A: 135-137, left). As indicated on a 1848 city plat (Figure 2), two areas were designated at this time, one for the Catholic cemetery and one for a city cemetery. Each cemetery was allocated a block of property measuring 105 varas $(291.66 \mathrm{ft})$ by 210 varas $(583.32 \mathrm{ft})$, separated by an east/west dividing line (Bexar County Archives [BCA], Bexar County Courthouse, San Antonio, Texas, 1848: City Survey Book 1). The council minutes note that the portion designated as the city cemetery was already in use as a "public burial ground" (CCM 1848: A: 135-137, left).

City council minutes record the acceptance of these plats with a dividing line running east/west through the center of the two cemeteries, and city streets bordering the four sides (CCM 1848:A:135-137, left). By 1904 these streets had become known as Commerce Street on the south, North San Saba Street on the east, Zavala Street on the north (now covered by Santa Rosa Hospital), and North Santa Rosa Street on 


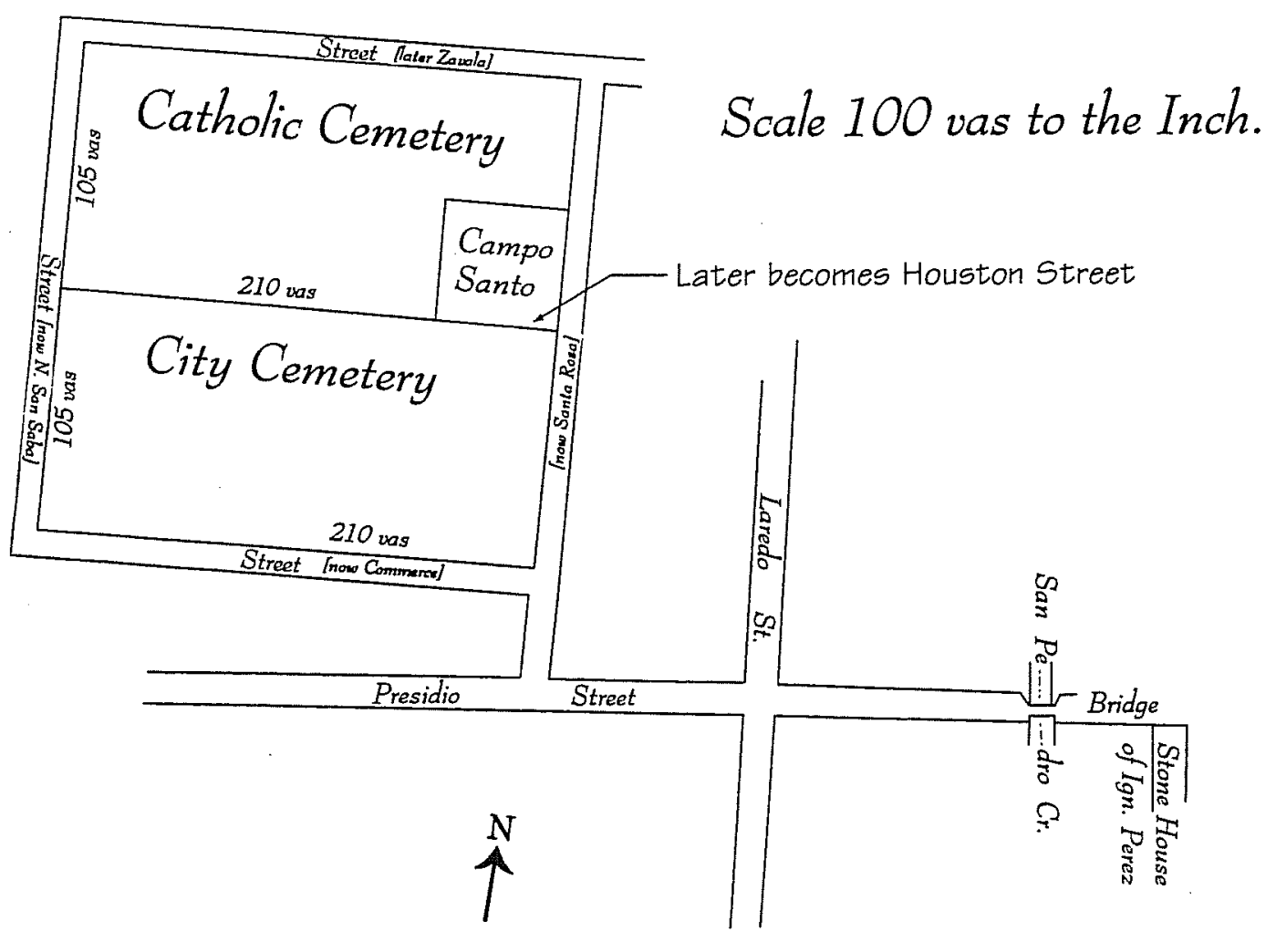

Figure 2. 1848 city plat for cemeteries. Adapted from the original 1848 Plat and Field Notes (BCA, 1848:City Survey Book 1. Vas=varas, approximately $2.8 \mathrm{ft}$.

the west (Sanborn Insurance Map 1904, United States Library of Congress Microfilm Collection, John Peace Library, University of Texas at San Antonio) (Figure 2).

The area to the south was evidently used as a public cemetery for only a short period because two years after it officially became the city cemetery, city council was again addressing the need for city cemetery lands. In October 1850 the council appointed a committee to assess the feasibility of locating a public cemetery on city property near the powder house east of the then city limits (SACH 1850:CCM B:111). Although a report was requested by the next meeting, action was not begun again until January 1853. At that time a resolution was passed for the survey of 20 acres of land on the hill northwest of the powder house to be called a city cemetery (SACH 1853:CCM B:203-204). By June 1853, seven city ordinances were approved for the management of this new city cemetery (SACH 1853:CCM B: 219-220).

In 1884 the city council decided to turn the old cemetery, unused since 1853 , into a city park. In a special meeting on January 8,1884 , a resolution was adopted to change the name of the then Milam Square, located northeast of the Alamo between Avenue C (Broadway) and Avenue D (Alamo Street) just south of Jones Avenue (City Directory [CD] 1883), to Maverick Square. The old cemetery was renamed Milam Square or Park in honor of the hero buried there (CCM, 1884: B:569).

By 1892, the dividing line between the two cemeteries (Figure 2) had been widened and converted into the city street known today as Houston Street (Sanborn Insurance Map 1892, 
United States Library of Congress Microfilm Collection, John Peace Library, The University of Texas at San Antonio). The right-of-way for Houston Street was evidently taken evenly from the two properties, covering approximately $30 \mathrm{ft}$ of each of the historic cemeteries and leaving each approximately $265 \mathrm{ft}$ wide (E. G. Trueheart, Eng'r., City Engineer's Office, Main Plaza Building, San Antonio, Texas, March 1900).

The distinction between the two old cemeteries, the city cemetery to the south and the Catholic cemetery to the north, evidently became blurred over time. For example, a 1911 newspaper article reporting the discovery of a human skull during street work on Houston Street, states that "Milam square and considerable land adjacent formed the old Spanish cemetery of this city many years ago" (San Antonio Express, 13 April 1911). And as recently as 1972, members of a local citizens' group, the Texas Hispanic-American History Foundation, in an attempt to preserve the cemetery from urban development, mistakenly identified Milam Park as “a 'campo santos,' or Catholic cemetery" (Weser 1972). Subsequently, the San Antonio Development Agency erected a series of granite plaques in the park bearing over 3,000 names of deceased people believed to have been buried there. This confusion has made it difficult to determine how many people were actually buried in the Protestant city cemetery and what, if anything, has happened to these historic burials. The Catholic cemetery was removed when Santa Rosa Hospital was built, and oral tradition indicates that all marked graves were moved at this time. Official documentation of these activities has not been located.

\section{PREVIOUS INVESTIGATIONS}

In January 1993, staff members from CAR, as part of the Phase I monitoring at Milam Park, located and exhumed the remains of Col. Benjamin Rush Milam from the center of the park (Tennis 1995). At one time this grave, in the center of the park, had been marked but the marker was inadvertently moved and the exact location lost. Plans for the construction of a kiosk in the center of the park required the relocation and removal of this burial. The remains were temporarily curated at the CAR laboratory, where they were analyzed by physical anthropologists from UTSA (Winkler 1995) and the Smithsonian Institution (Sandness and Owsley 1995). Upon completion of the renovation of the park, Col. Milam's remains were reinterred, with proper ceremony, in the park at the base of the monument bearing his statue. During this phase of investigation, the historic 1840 s city cemetery now known as Milam Park was assigned a state archaeological site trinomial number: 41BX922.

\section{SOIL DESCRIPTION}

Houston Black Clay is the dominant soil type in the downtown San Antonio area, including Milam Park. This soil is dark gray to black. Its main characteristic is its potential for shrinking and swelling with changes in moisture and temperature. There is typically a zone 3-6 ft below the surface where the soil matrix is constantly mixed and turned. This action can cause displacement or disruption in subsurface deposits such as archaeological features (Collins 1996). A layer of recent fill dirt is present above the historic surface in all areas of the park. This layer of fill varied in thickness from 8-14 inches in different areas of the park.

\section{SHOVEL TESTS AND MONITORING}

\section{PROJECT DESIGN}

The level of the monitoring and testing for this phase of investigation at Milam Park was based on two main tenants. First, lacking clear documentation regarding the status of historic burials in the park, careful monitoring would be required during all phases of renovation. Second, details obtained during Phase I investigations revealed that a sixinch layer of modern landscape sand and soil covered much of the present surface. The burial of 
Col. Milam, exhumed during Phase I investigations, was discovered at a depth $31 / 2 \mathrm{ft}$ below the modern surface of the park, approximately three feet below the identified historic surface (Tennis 1995). All parties involved in the park renovation were aware of these parameters and original plans were designed to minimize construction impact below two feet from the modern surface.

Archaeological interpretations of the subsurface deposits were continually reevaluated as monitoring and shovel tests were completed.

\section{PLAYGROUND AREA MONITORING}

For three days, November 1-3, 1993, two staff archaeologists monitored ground preparation activities for the installation of playground equipment in the central portion of the park, east of the kiosk. A series of 55 holes (12 inches in diameter) and 31 holes (24 inches in diameter) was bored to accommodate equipment footings (Figure 3). Footing depths did not exceed $2.9 \mathrm{ft}$ below the modern surface. Numerous PVCencased water and electric lines were encountered approximately 20 inches below the surface on the north side of the playground, along with large pieces of concrete and limestone, possibly turned under when the PVC lines were installed. No artifacts were recovered from this disturbed portion of the playground area. Post-1900 artifactsincluding several square and round nails, a metal belt buckle, a rhinestone pin, numerous cow bones, and three coins (a 1903 Indianhead penny, a 1919 penny, and a 1954 nickel)-were recovered from the bore holes in the southeast section of the playground.

\section{SHOVEL TESTS}

During the first week of December 1993, 12 shovel tests were excavated in areas designated for impact during upcoming landscape activities (Figure 3). These tests revealed a layer of recent fill dirt above the historic park surface. Along the west and south sides of the park and in the central section between the Milam monument and the kiosk, the layer of fill dirt and recent disturbances extends to a depth of 12-14 inches below the surface. Along the north edge of the park, the disturbed area extends to a depth of 8 inches below the surface. The historic surface-identified by a soil change, animal bone, and lead glazed ceramicswas encountered 2 inches below the modern surface in the east end of the park. This information was used to modify landscaping plans.

\section{SIDEWALK AND ACCESS RAMP MONITORING}

Grading activities for sidewalks and excavations for access ramps in the north and south central section and in each corner of the park were monitored during the second week of December 1993 (Figure 3). In each access ramp excavation, previous construction disturbances of unknown origin were noted 14-16 inches below the surface. These activities had no adverse effects on cultural resources.

\section{SEWER-LINE TRENCH MONITORING}

Trenching operations for the installation of sewer lines were conducted and monitored March 7-10, 1994 (Figure 3). Trenches for major lines connecting to the city sewer under Commerce Street were placed at each end of the park. The line on the west end of the park, five feet east of the Milam monument, is 51 inches below the surface at its deepest point. The line at the east end of the park parallels the east side of the new sidewalk and is also 51 inches at its deepest point. The depth of trenches for subsidiary lines in the north section of the park varied from 14-41 inches below the surface. No adverse effects on cultural resources were caused by these trenching activities. 


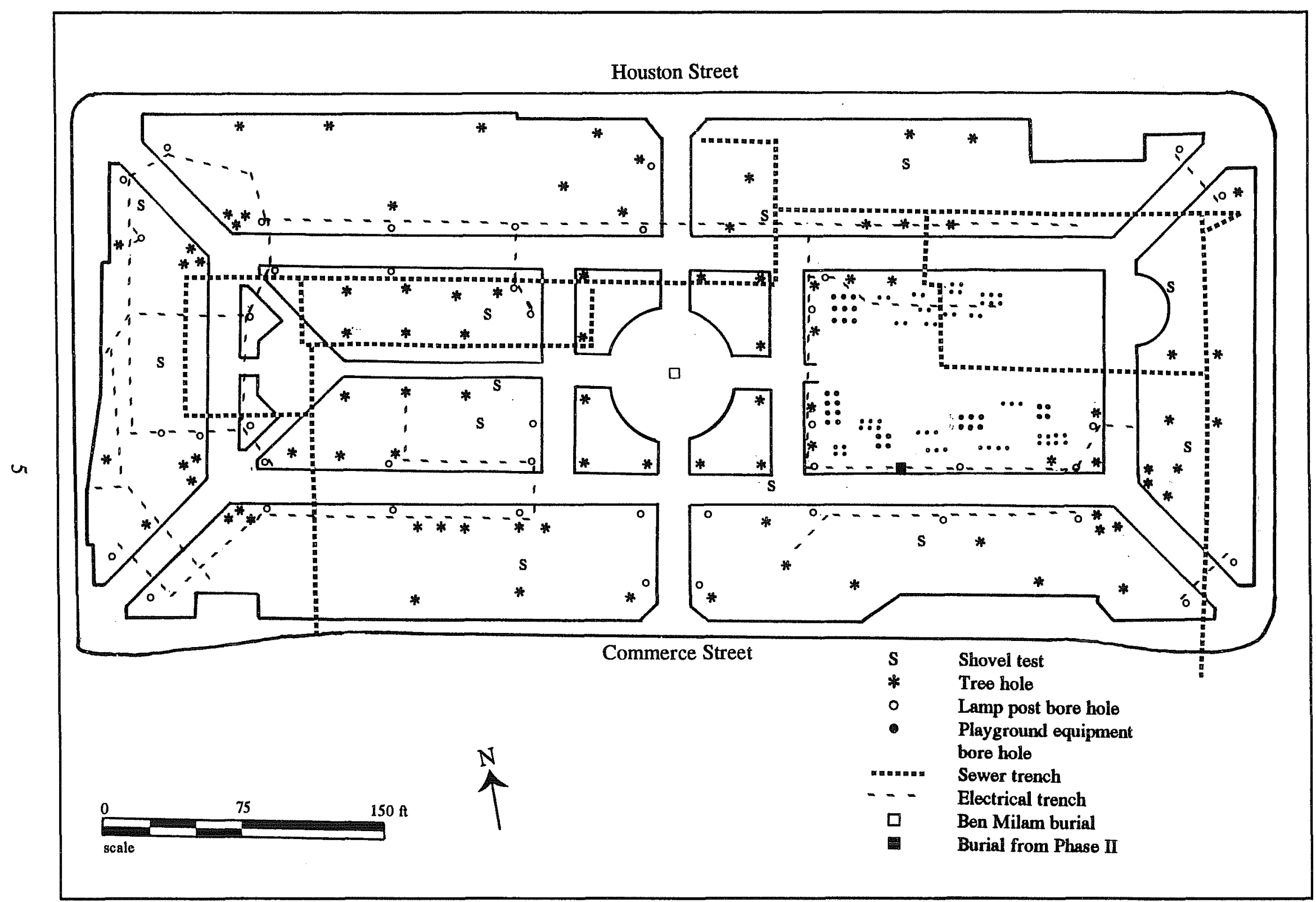

Figure 3. Site map showing monitored excavations and burial location. 


\section{LIGHT POLE AND ELECTRIC TRENCH MONITORING}

During the first week of April 1994, boring for installation of new light poles and excavation of trenches for related electrical wiring were monitored (Figure 3). Light pole foundation holes were bored to a maximum depth of 36 inches below the surface. Trench depths varied from 12-24 inches below the surface. No cultural resources were encountered in the east, west, north, or central sections of the park during these activities. However, during excavation of the electrical trench on the south side of the park, at a point $22 \mathrm{ft}$ east of the southeast corner of the playground and at a depth of 18 inches below the surface, a piece of bone was observed on the trench wall (Figure 3). Close inspection indicated the bone was human. Further investigation revealed part of a lower mandible in the south wall of the trench. Monitoring of the remainder of this trench-the last one planned-continued while Dale Bransford of the city Parks and Recreation Department was notified of the possible burial. Plans for further investigation and exhumation were made for the following day. No other cultural resources were encountered during this phase of the renovation.

\section{SEWER HOOK-UP MONITORING}

On the evening of September 26, 1994, the sewer line at the south end of the park was connected to the main sewer in the center of Commerce Street (Figure 3). This operation was monitored by CAR staff due to the uncertainty of the southernmost extent of the portion of the park that had been used as a cemetery. The trench began at the southeastern edge of the park and continued south for 49 $\mathrm{ft}$ to the center of the street. The trench was 22 inches deep at the park edge, gradually increasing to a maximum depth of 42 inches in the center of the street. Throughout the length of the trench, recent disturbances varying in thickness from 10-18 inches below the surface were observed. The underlaying Houston Black clay appeared undisturbed. No cultural resources were encountered during this operation.

\section{LANDSCAPE MONITORING}

The final project in the renovation planrelandscaping-involved planting 91 new trees, the majority of which are spaced around the perimeter of the park (Figure 3). All holes were dug by hand between November 11, 1994, and January 9, 1995. Maximum depth never exceeded three feet and no cultural resources were encountered during this portion of the project.

\section{EXHUMATION}

On April 8, 1994, CAR staff members assembled to remove the remains of the human burial revealed the previous day during excavation of a utility trench. Portions of the remains (the left mandible and four teeth) were visible $56 \mathrm{~cm}$ below the surface in the south wall of the trench which runs east-west roughly $35 \mathrm{~m}$ north of the south edge and $100 \mathrm{~m}$ west of the east edge of the park (Figure 3). A 1-x-1-m unit was opened on each side of the trench above the exposed bones. The upper $30 \mathrm{~cm}$ of soil was removed by shovel, and trowel excavations in both units continued to the top of the burial. Bamboo skewers were used to remove soil directly associated with the skeletal remains to prevent damage to the bones. The remains were uncovered in situ, photographed, and mapped (Figure 4).

Only small pieces of the wooden coffin remained: a section in the area of the right shoulder and portions of the bottom. The outline formed by vertical and horizontal nails found in situ around the remains indicate that the coffin represents the "toe-pinch" style common in the mid-nineteenth century. The length of the coffin, based on the distance between the vertical nail at the head and the horizontal nail at the foot, is $175 \mathrm{~cm}$. Coffin width is estimated to have been $45 \mathrm{~cm}$ at the shoulders, tapering to $15 \mathrm{~cm}$ at the foot. 


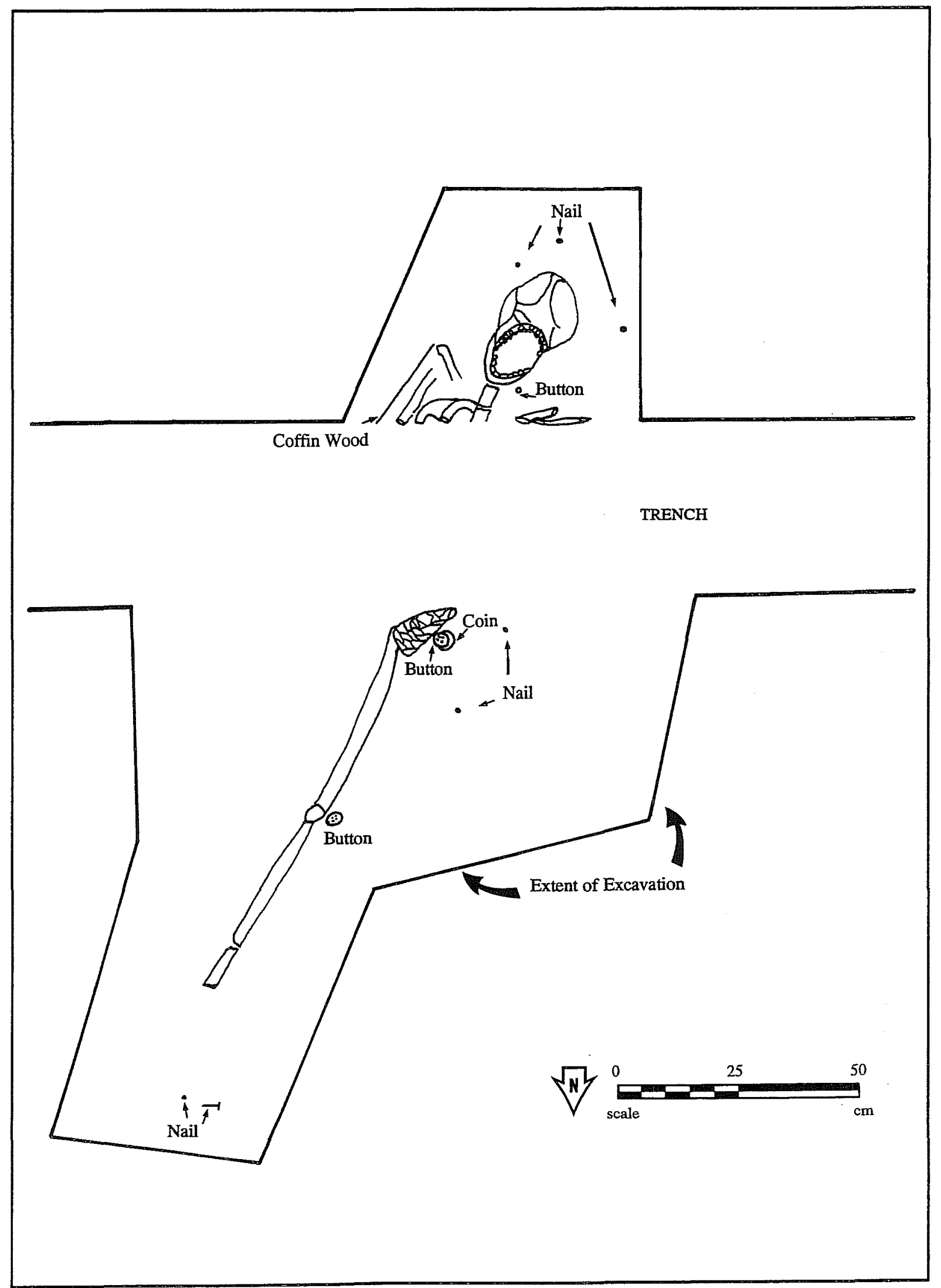

Figure 4. Plan view of burial. 
As evident in Figure 4, the backhoe trench bisected the remains, removing the majority of the torso from the shoulders to the hips. The burial is oriented slightly east of north/south with the head to the south. The uppermost portion of the skull was encountered $54 \mathrm{~cm}$ (approximately 21 inches) below the surface. Extensive crushing both laterally and horizontally was evident in the skull and postcranial bones so that the burial is no more than $8 \mathrm{~cm}$ thick at the pelvis. The location of the burial beneath an interior park roadway used by maintenance vehicles undoubtedly contributed to the fragmentation process.

Dirt from the backhoe trench in the area of the burial was inspected and all bone fragments were collected. Additional bone fragments were noted in several of the larger clumps of dense clay and these were also collected and returned to the CAR laboratory where they were soaked and all bone fragments removed. Besides a right patella recovered from the backhoe dirt, no evidence of the right leg was found.

After the burial was removed, the original excavation area was enlarged one meter on either side of the burial to look for evidence of previous disturbances that might account for the missing right leg. No recent disturbances were noted and the homogeneous nature of the black clay in the park would probably have erased evidence of earlier disturbances.

\section{OSTEOLOGICAL ANALYSIS}

Douglas W. Owsley and Cynthia L. Tennis

In August 1994, the skeletal remains of the burial exhumed during the second phase of renovation at Milam Park were transported to the Smithsonian Institution for analysis. Physical anthropologists at the Smithsonian had participated in the analysis of the skeleton of Ben Milam exhumed from the park in 1993 (Sandness and Owsley 1995) and were interested in obtaining comparative data from this contemporary historic burial.

\section{CONDITION AND \\ OSTEOLOGICAL INVENTORY}

Although the bones are generally solid and dense, most of the cranial and postcranial bone are highly fragmented making measurements impossible. Most of the fractures are fairly old.

The cranium, although fragmented, is complete and has been partially reconstructed. The mandible and left and right maxilla as well as the hyoid bone are present. The skull shape is brachycephalic. The posterior parietal show external erosion of the cortex, a postmortem process related to burial with that surface down.

Identifiable postcranial bones (all fragmented) are as follows:

- portions of the first through sixth cervical vertebrae with neural arches attached

- fragments of thoracic vertebrae 1-9

- partial right humerus, proximal end only

- partial left radius, proximal end only

- partial left ulna, proximal end only

- nearly complete right scapula

- complete right clavicle and mid-section of the left clavicle

- fragmented portion of the sacrum

- left femur (fragmented) and right femur (distal end only)

- left tibia (missing distal end) and right tibia (proximal end only)

- left fibula (fragmented)

- left and right patella (right not in situ)

- foot bones, left talus and calcaneus

- many small, unidentifiable fragments

The following teeth are present:

-maxillary

- left first and second incisors

- left canine

- left first and second premolars

- left first, second, and third molars

- right second premolar

- right first, second, and third molars

-mandibular

- left first and second incisors

- left canine

- left first and second premolars 
- left first, second, and third molars

- right first and second incisors

- right canine

- right first and second premolars

- right first, second, and third molars

The right maxillary incisors and canine were not recovered because of postmortem loss.

\section{PATHOLOGY}

Dental

Tooth wear is slight except for well-defined wear patterns between the maxillary and mandibular left canines and second incisors. Similar wear is present between the right mandibular canine and first premolar. These patterns, known as pipe facets, are consistent with wear resulting from excessive pipe smoking. The onset of carious lesions is noted on the occlusal surfaces of the right maxillary and left mandibular third molars. Also, about half of the occlusal surfaces of the left maxillary third molar, the right mandibular third molar, and the left mandibular first molar have been destroyed by caries. Caries is also present on the buccal surface of the right mandibular third molar and the left mandibular second molar. The maxilla shows an active alveolar abscess in the left first premolar. The right first premolar was lost antemortem and the socket has resorbed. Moderate to heavy calculus deposits are present on all teeth but the teeth are not stained.

Skeletal

No ethesophytes, bone spurs, or other pathological conditions were observed.

\section{PHYSICAL CHARACTERISTICS}

\section{Sex}

The general physical characteristics are consistent with designation as a male. The skull has a fairly small but well-developed occipital protuberance, slight development of brow ridges, and a fairly steep slope to the forehead. Other cranial morphology suggesting that the sex is male includes blunt supraorbital margins, a small but defined supramastoid crest, and large zygoma. The mandible is relatively small but with a prominent chin. The roots of the teeth, especially the canines, are fairly long and the mandible has a slight gonial flair, especially on the right side. Although the muscle attachment sites are not particularly pronounced, long bone size and robusticity fall within the male range.

\section{Ethnicity}

Features of the face include moderate facial flatness of the maxillary bones without welldefined canine fossae. The nasal opening is moderately wide, but exact measurement is difficult because of postmortem breakage. The nasal bones are prominent and have a moderately steep angle. The zygomaxillary suture follows the characteristic form of Native Americans. The left maxillary incisor shows stage three wear and attrition on the incisive third of the lingual surface; however, the general form suggests a slight degree of shovel-shaped morphology. The mandibular incisors do not show evidence of shoveling. Overall dental cusp morphology is fairly simple and there are no Carabelli's cusps. The general appearance is most consistent with Hispanic/ Caucasian, not black and not Native American. Cranial measurements cannot be taken.

Age

Epiphyseal closure of the long bones was complete, as was dental development. Dental wear is slight for the posterior teeth and moderate for the anterior, but this can be linked to the pipe wear facets.

The external cortical surface of the bone is relatively smooth and all areas of trabecular bone are compact and dense. There are no intertrochanteric spicules in the proximal left femur and all available joint surfaces are free of arthritic changes. Vertebral facets and vertebral centra also do not show arthritic changes. The general profile suggests an individual $30-39$ years of age, with the best estimate between 30-34. 


\section{ASSOCIATED ARTIFACTS}

One small, four-hole, bone button measuring 10.7 $\mathrm{mm}$ in diameter was recovered in situ from the matrix associated with the remaining upper torso. Two larger, four-hole, bone buttons measuring $17.4 \mathrm{~mm}$ in diameter were recovered immediately adjacent to the left pelvis, possibly remnants of trouser buttons. Also adjacent to the left pelvis and directly beneath one of the large wooden buttons was a large silver coin measuring $32 \mathrm{~mm}$ in diameter (Figure 5). This coin, probably from the pants pocket of the individual, is a Mexican 8 reales, dated 1847 , bearing a "liberty cap" on one side and a "hooked-necked eagle" on the other (Hodson and Obojski 1970).

\section{CONCLUSIONS}

The condition of the skeleton, the style of the coffin, and the 1847 coin found in association with the skeletal remains all coincide with the 18481853 use of this historic city cemetery. The results of the osteological analysis indicate that the remains are those of a Hispanic/Caucasian male who smoked a pipe and was between the ages of 30-34 when he died. The only pathology observed was dental. No pathological evidence was found to support or reject antemortem loss of the right leg. Whether the leg was missing before death, was the cause of death, or was separated from the rest of the burial by a previous disturbance are questions which remain unresolved.

\section{CONCLUSIONS AND RECOMMENDATIONS}

During this 14-month project, construction excavations were monitored in all areas of Milam Park (Figure 3). Modern layers of fill dirt and recent disturbances were present in all areas of the park. The disturbed areas extend to varied depth across the park, from 2 inches below the surface in the east end of the park, to 8 inches below the surface along much of the north side, and 12-14 inches below the surface along the west, south, and central sections.

All observations indicate that no activities of historical significance occurred in this block of downtown San Antonio that were not directly connected to the site's use as a city cemetery. From the extensive amount of subsurface area investigated, only one historic burial was encountered, suggesting that most of the city cemetery burials were relocated at some point in the past. We cannot rule out the possibility that other isolated graves remain in Milam Park, and recommend continued monitoring of subsurface modifications in this potentially sensitive area. However, the low density of cultural material encountered so far indicates that monitoring remains an efficient, effective, and appropriate method of cultural resource management in Milam Park.

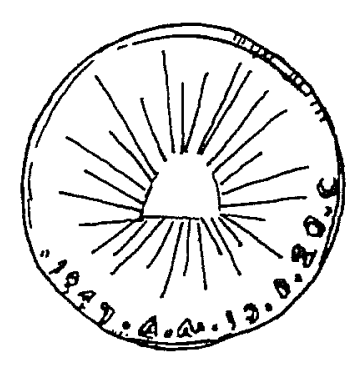

a

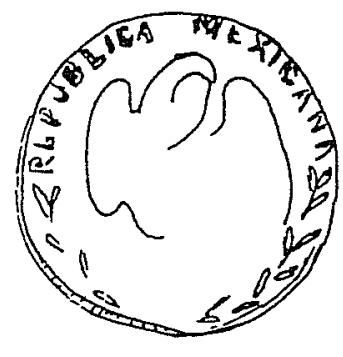

b

Figure 5. 1847 Mexican 8 reales. a. liberty cap; b. hookednecked eagle. Shown actual size. 


\section{REFERENCES CITED}

Collins, M. B.

1996 Quaternary Geomorphology of the San Antonio Dome Project Area. In Archaeology at the Alamodome: Investigations of a San Antonio Neighborhood in Transition, Volume II, Excavations and Artifact Distribution Analysis, by G. K. Wright. Archaeological Survey Report, No. 237. Center for Archaeological Research, The University of Texas at San Antonio. In review.

Hodson, B., and R. Obojski

1970 Illustrated Encyclopedia of World Coins. Doubleday, New York.

San Antonio Express [San Antonio, Texas]

1911 Workmen Dig Up Skull in Street: Bones Are Unearthed by Traction Company Laborers Near Santa Rosa Hospital, 13 April.

Sandness, K. L., and D. W. Owsley

1995 Analysis of the Skeletal Remains. In Exhumation of a Hero, Colonel Ben Milam: Milam Park Renovation, Phase I, by C. L. Tennis, pp. 20-24. Archaeological Survey Report, No. 223, Center for Archaeological Research, The University of Texas at San Antonio.

Tennis, C. L.

1995 Exhumation of a Hero, Colonel Ben Milam: Milam Park Renovation, Phase I. Archaeological Survey Report, No. 223, Center for Archaeological Research, The University of Texas at San Antonio.

Weser, D.

1972 Historic Debate Again Is Looming, San Antonio Express 13 September.

Winkler, B.

1995 Analysis of the Ben Milam Skeleton. In Exhumation of a Hero, Colonel Ben Milam: Milam Park Renovation, Phase I, by C. L. Tennis, pp. 13-19. Archaeological Survey Report, No. 223, Center for Archaeological Research, The University of Texas at San Antonio. 


